\title{
ANALISIS KEGAGALAN PEGAS DAUN KENDARAAN BUS DENGAN KAPASITAS 7 TON
}

\author{
Basori $^{(*)}$, Asmawi, dan Togar Pasaribu \\ Program Studi Teknik Mesin \\ Universitas Nasional \\ ${ }^{(*)}$ email: basori@ civitas.unas.ac.id
}

\begin{abstract}
ABSTRAK
Pegas daun merupakan salah satu komponen utama dalam sistem suspensi pada sebuah kendaraan. Apabila terjadi kerusakan pada pegas daun tersebut dampak yang dihasilkan dapat mengakibatkan terjadinya kecelakaan. Penelitian ini bertujuan untuk mendapatkan faktor penyebab terjadinya kegagalan pada pegas daun bus dengan kapasitas 7 ton. Metode yang digunakan dalam penelitian ini adalah pengujian metalografi menggunakan ASTM E 3 dan ASTM E 112, pengujian kekerasan dilakukan dengan standar kekerasan ASTM E 92 dan SNI 19-0409-1989, dan pengujian komposisi kimia menggunakan uji ASTM A 751. Hasil pengujian makro pada pegas daun yang mengalami patah berada di sebelah kiri dengan lebar $80 \mathrm{~mm}$ dan panjang $100 \mathrm{~mm}$, hasil pengujian mikrostruktur pada patahan terlihat adanya Sulphide Stress Cracking (SSC) dan terbentuk martensit halus serta austenite sisa berwarna putih. Sedangkan hasil uji komposisi kimia menunjukkan adanya penurunan unsur kimia $\mathrm{Cr}$ sebesar $0,11 \%$ dan unsur kimia $\mathrm{C}$ sebesar $0,075 \%$. Hal ini disebabkan oleh kelelahan material akibat pembebanan dinamis.
\end{abstract}

Kata Kunci : Pegas daun, analisis kerusakan, metalografi, kekerasan, komposisi kimia

\begin{abstract}
Leaf spring is one of the main components in the suspension system on a vehicle. If there is damage on the leaf spring of the impact that is produced can lead to the occurrence of the accident. This study aims to find factors that cause the occurrence of a failure on the leaf spring bus with a capacity of 7 tons. The method used in this research is the testing of metallographic using ASTM E 3 and ASTM E 112, hardness testing is done with standard hardness ASTM E 92 and ISO 19-0409-1989, and chemical composition testing using ASTM A 751. The results of testing the macro on the leaf spring that broke was on the left with a width of $80 \mathrm{~mm}$ and a length of $100 \mathrm{~mm}$, the results of the testing of microstructure on the fracture visible presence of Sulphide Stress Cracking (SSC) and formed martensite smooth as well as residual austenite is colored white. While the test results of chemical composition showed a decrease in the chemical element Cr of $0.11 \%$ and a chemical element $C$ of $0.075 \%$. This is caused by the material fatigue due to dynamic loading.
\end{abstract}

Keywords: Leaf spring, failure analysis, metallography, hardness, chemical composition.

\section{Pendahuluan}

Manusia dalam menjalankan aktifitas sehari-hari dimudahkan oleh adanya alat transportasi. Alat transportasi umum yang biasa digunakan untuk pengangkutan orang antara lain: Bus, Kereta Api, Sepeda Motor, dan lain sebagainya. Masing-masing memiliki kemampuan angkut yang berbeda-beda. Bus merupakan salah satu kendaraan pengangkutan orang yang banyak diminati. Di samping kenyamanan, banyak orang memilih bus karena nilai ekonomis, aman dan mampu menempuh perjalanan yang sangat jauh. Bus merupakan alat pengangkutan orang dengan berat lebih dari 3.500 kilogram. Kenyamanan merupakan faktor terpenting bagi pengendara maupun penumpang yang ada di dalamnya. Di samping fasilitas yang dilengkapi oleh armadanya, juga tidak kalah penting adalah kenyamanan dalam mengatasi masalah getaran pada bodi bus. Hal ini tentu berkaitan erat dengan sistem suspensi. Suspensi adalah rangkaian komponen yang berfungsi untuk meredam dan menyerap getaran akibat permukaan jalan yang tidak rata, berlubang, menikung tajam dan pengereman mendadak agar getaran tidak diteruskan ke bodi bus. Sistem suspensi terpasang di antara roda dengan rangka kendaraan. Komponen utama sistem suspensi adalah pegas. Pegas yang digunakan pada kendaraan jenis bus adalah pegas daun (Leaf Spring). Pegas daun memiliki bentuk berupa bilah baja tipis memanjang dengan ukuran tertentu yang mampu menerima beban dan gaya dari bus. Ketika bus menerima beban, maka pegas daun akan mengalami defleksi dan akan kembali seperti bentuk semula setelah beban dilepaskan. Salah satu bus telah mengalami kerusakan pegas daun berupa patah, sehingga penulis tertarik untuk melakukan pengujian. Faktor penyebab kerusakan pada pegas daun pada umumnya adalah adanya beban yang berlebihan, usia pegas yang sudah melewati masa pakai, permukaan jalan yang dilalui rusak, serta kurangnya perawatan oleh user. Berdasarkan permasalah di atas, maka pada penelitian ini akan membahas tentang penyebab kerusakan atau patahnya pegas daun kendaraan jenis bus yang memiliki kapasitas 7 ton. Dengan diketahuinya penyebab kerusakan pada pegas daun maka diharapkan dapat menjadi masukan untuk pemangku 
kepentingan, baik pemilik maupun manajemen pengelola bus untuk melakukan tindakan-tindakan preventive dan maintenance terhadap pegas daun yang terdapat pada bus, sehingga usia pakai pegas daun pada bus dapat bertahan lebih lama dan kenyamanan serta keamanan sistem suspensi bus dapat terjaga dengan baik.

\section{Metodologi Penelitian}

Metodologi penelitian analisis yang digunakan pada kegagalan/kerusakan pegas daun bus adalah metode uji laboratarium yaitu pengamatan metalografi, pengujian kekerasan, komposisi kimia terhadap material pegas daun bus. Tahapan analisis kegagalan pegas daun bus terdiri dari pemilihan lokasi sample uji, pemotongan untuk mendapatkan sample uji, preparasi dan pengujian sample uji serta analis dari pengujian sample. Seluruh tahapan pengujian tersebut ditunjukkan dalam diagram alir pengujian seperti diperlihatkan pada gambar 1 .

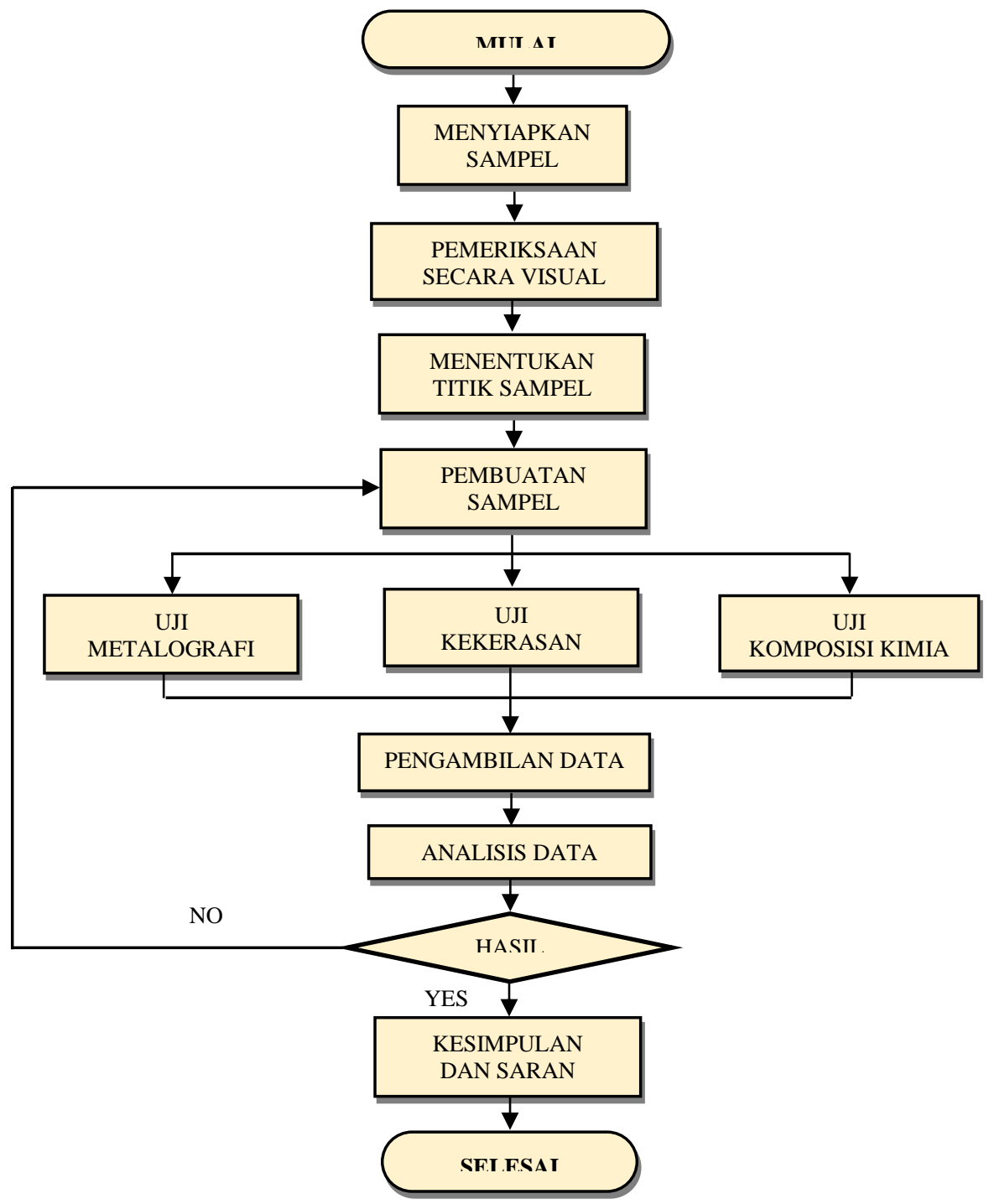

Gambar 1. Diagram alir analisis kegagalan pada pegas daun bus

\subsection{Bahan Penelitian}

Bahan yang digunakan pada penelitian/pengujian adalah pegas untuk bus yang mengalami cacat atau patah. Bahan penelitian lain yang digunakan adalah resin dan pengeras untuk membingkai spesimen uji, kertas amplas, alumina dan larutan nital $2 \%$. Pegas yang dijadikan dalam pengujian ditunjukkan pada gambar di bawah ini : 


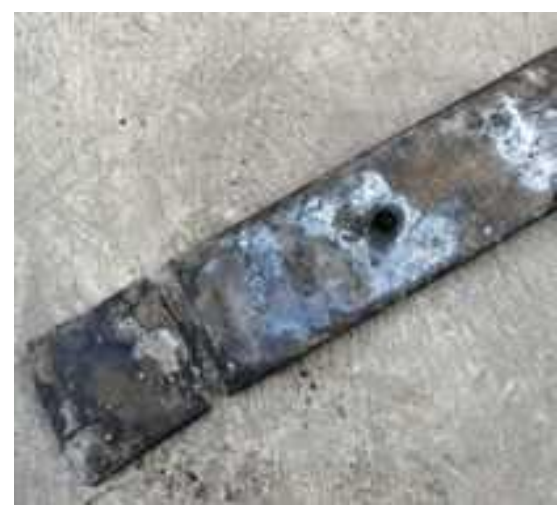

Gambar 2. Komponen pegas daun bus

\subsection{Peralatan Penelitian}

Peralatan yang digunakan dalam penelitian ini adalah :

a. Mesin gergaji digunakan untuk memotong pegas daun bus sebagai bahan dalam pembuatan sampel.

b. Mesin potong untuk digunakan membuat sampel

c. Mesin gerinda dalam poles untuk meratakan dan menghaluskan permukaan sampel.

d. Mikrosop optik digunakan untuk pengamatan mikrostruktur sampel.

e. Micro vickers untuk menentukan kekerasan mikro sampel.

f. Spektrometer digunakan untuk menentukan komposisi kimia sampel.

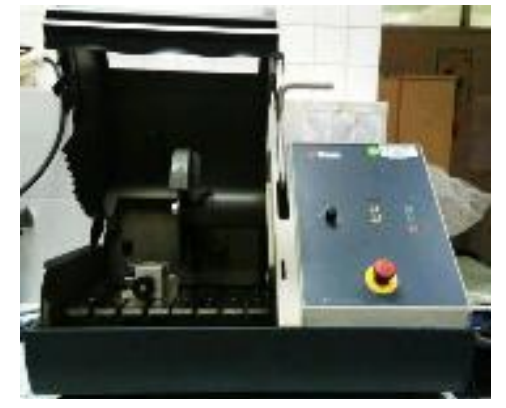

(a)

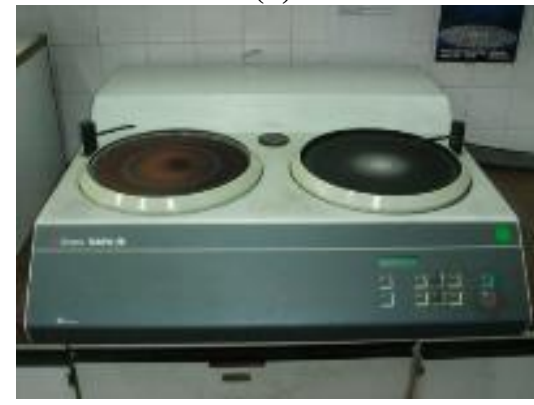

(c)

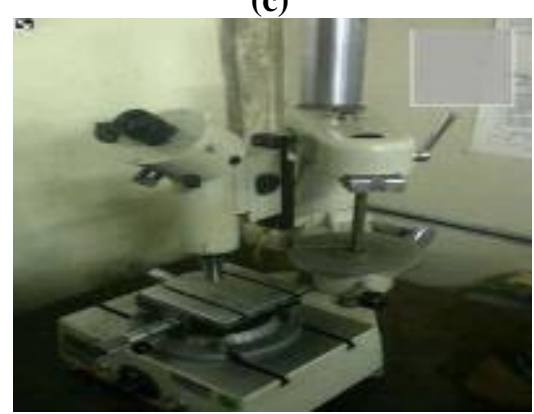

(e)

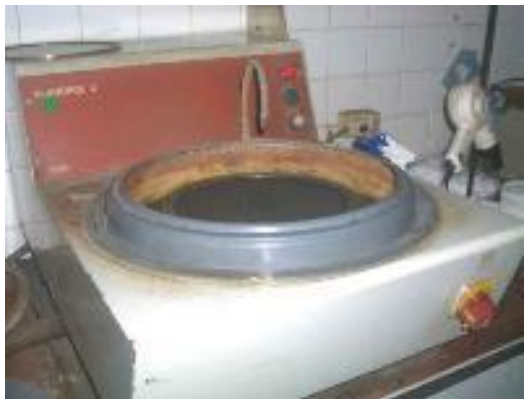

(b)

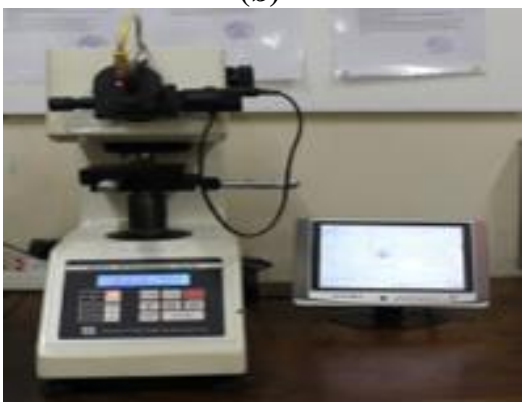

(d)

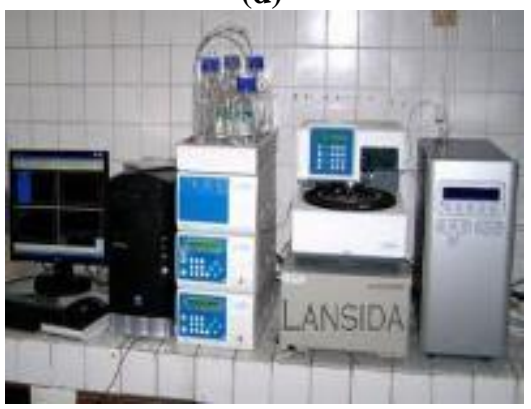

(f)

Gambar 3. Peralatan penelitian analisis kerusakan pegas daun bus

3. Hasil dan Pembahasan 
Penelitian terhadap kerusakan pegas daun meliputi pemeriksaan visual, makrostruktur, mikrostruktur, pengujian kekerasan dan pengujian komposisi kimia. Hasil dan pembahasan disajikan dalam bentuk tabel data dan gambar grafik.

\subsection{Makrostruktur}

Pengujian makrostruktur dilakukan pada daerah permukaan pegas daun yang mengalami kerusakan. Pemeriksaan dilakukan menggunakan mikroskop stereo dengan pembesaran 6x, 12x dan 25x seperti ditunjukkan pada gambar 4.

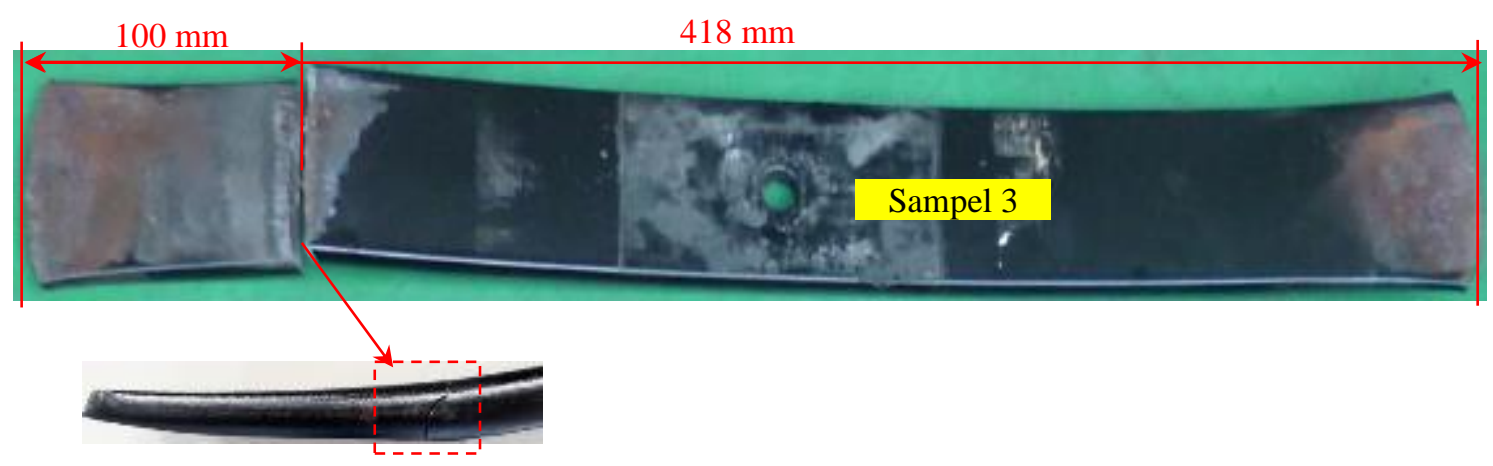

Patah di daerah taper

(a)

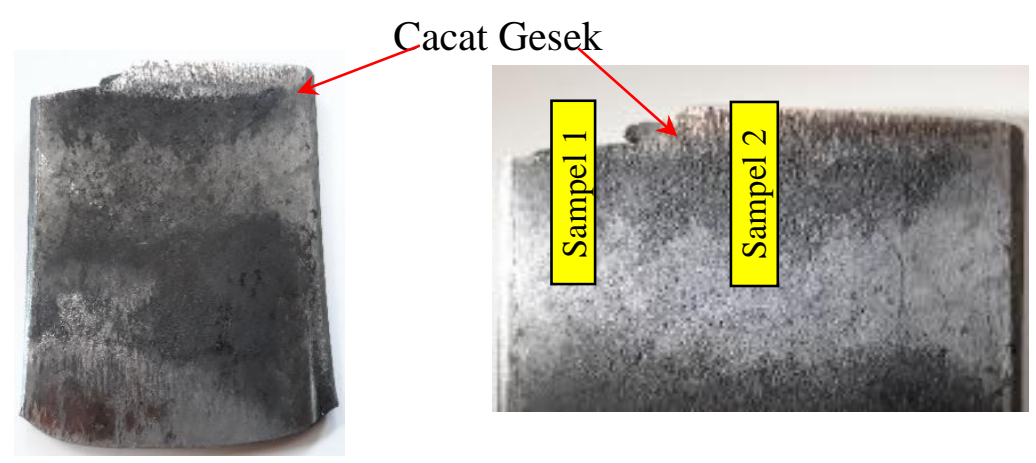

(b)

Gambar 4. Pegas daun bus yang mengalami cacat gesek (a) sampel 1 (b) sampel 2 dan 3

Pada gambar 4. bagian (a) menunjukkan pegas daun sebelum mengalami patah dengan ukuran panjang $418 \mathrm{~mm}$ dan lebar $80 \mathrm{~mm}$, sedangkan pada bagian yang mengalami patah berukuran panjang $100 \mathrm{~mm}$. Terlihat pada gambar bagian (b) yang menunjukkan adanya cacat gesek pada daerah patahan pegas daun yang diakibatkan karena gesekan antara pegas daun dengan pengikat pegas.

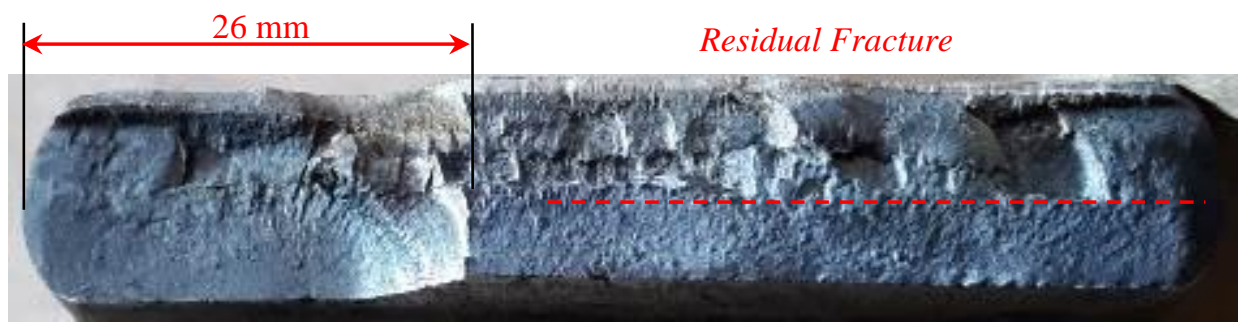

(a) Gambar patahan pegas tampak atas 


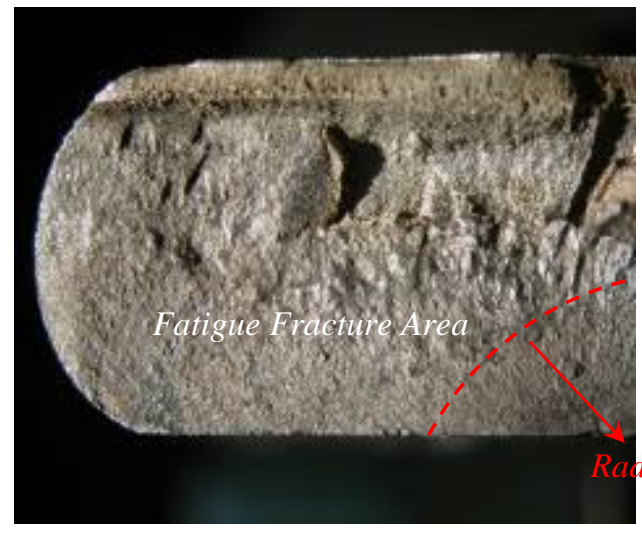

(b) Gambar patahan pegas tampak atas dengan 12x pembesaran

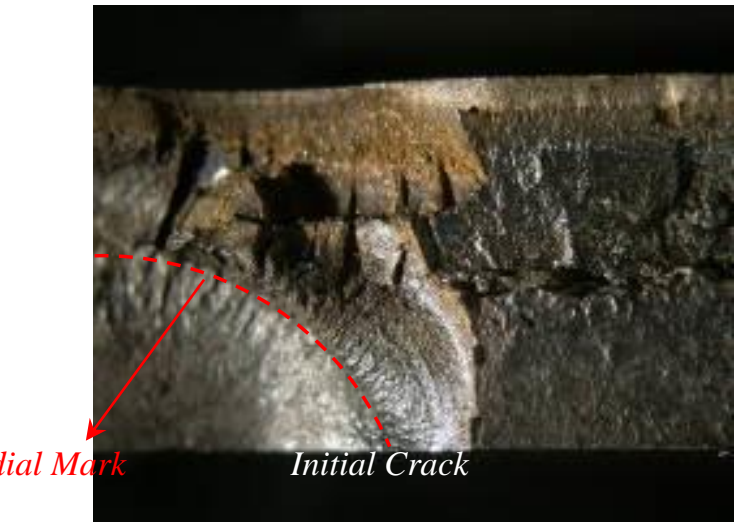

(c) Gambar patahan pegas tampak atas dengan $25 \mathrm{x}$ pembesaran

Gambar 5. Daerah patahan pada pegas daun

Gambar 5. bagian (a) pada sisi kiri memperlihatkan daerah awal mula terjadinya retak (initial crack) sepanjang $26 \mathrm{~mm}$ dan pada sisi bagian kanan merupakan daerah yang terkena dampak pembebanan dinamis. Sedangkan pada gambar (b) dan (c) menunjukkan daerah patahan dengan pembesaran 12x dan 25x.

\subsection{Mikrostruktur}

Pengujian mikrostruktur dilakukan terhadap pegas daun bus yang mengalami kerusakan. Pengujian dilakukan dengan pembesaran 100x dan 500x seperti ditunjukkan pada gambar 6. Pengujian sampel dilakukan menggunakan larutan etsa : Nital dengan kadar campuran $2 \%$.

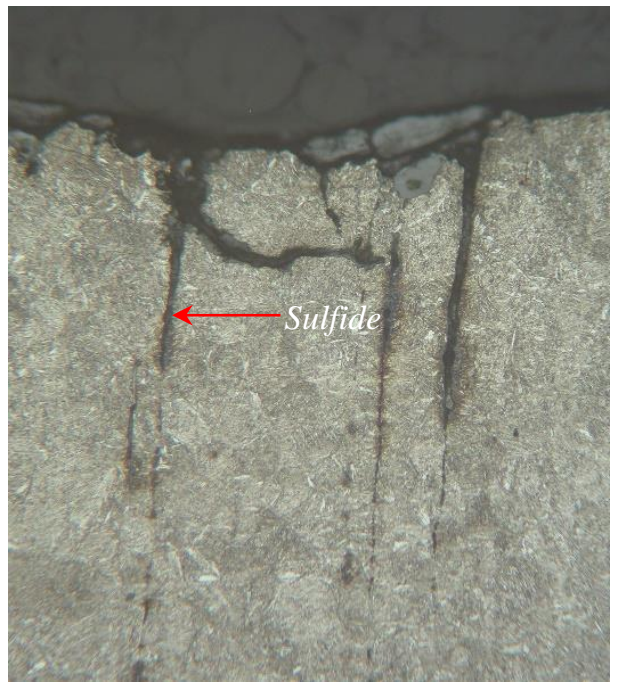

(a) Pembesaran 100x

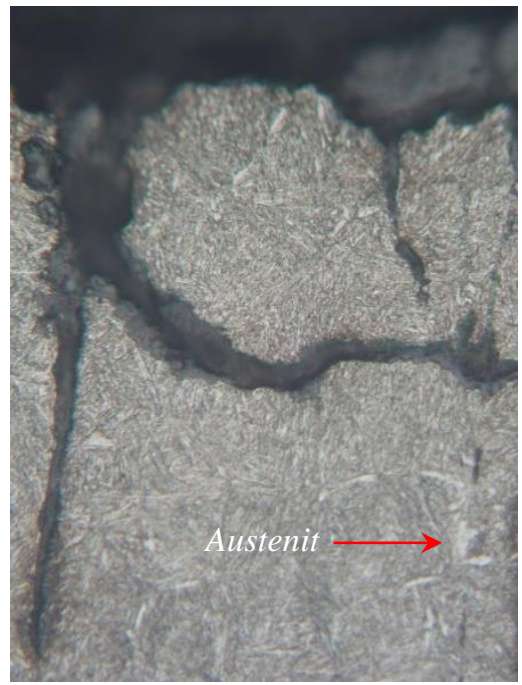

(b) Pembesaran 500x

Gambar 6. Hasil pengujian mikrostruktur pada sampel 1.

Pada gambar 6 bagian (a) menunjukkan retakan yang disebut Sulphide Stress Cracking (SSC). SSC merupakan retakan yang terjadi karena atom hidrogen berdifusi ke dalam logam tetapi tetap berada dalam keadaan larutan padat dalam kisi kristal. Hal ini menyebabkan terjadinya penurunan terhadap sifat keuletan dan deformasi logam. Pada gambar bagian (b) menunjukkan struktur mikro yang terbentuk adalah berupa martensit halus dan austenite sisa berwarna putih. Martensit merupakan salah satu fasa yang terbentuk pada struktur logam yang memiliki sifat keras dan getas, sehingga logam yang berada pada fasa tersebut apabila mendapatkan pembebanan dinamis akan cepat mengalami kerusakan yang berujung patah. 


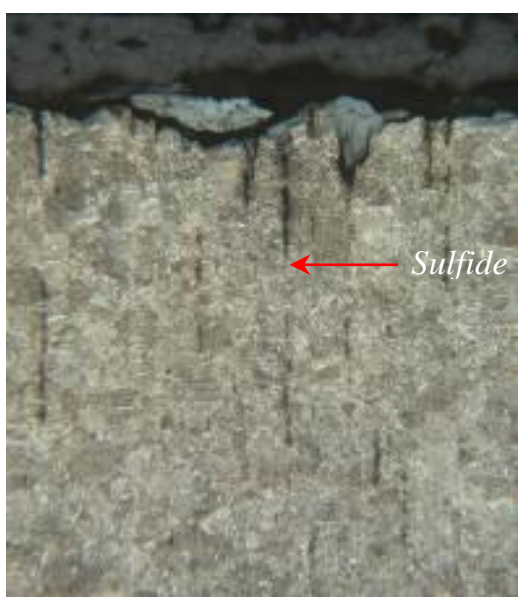

(a) Pembesaran 100x

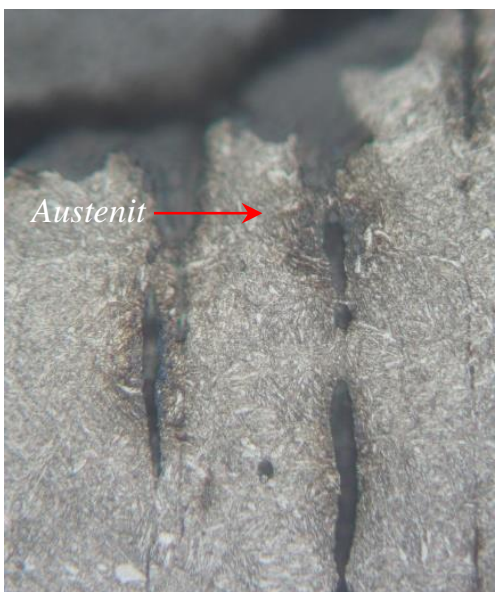

(b) Pembesaran 500x

Gambar 7. Hasil pengujian mikrostruktur pada sampel 2.

Pengujian mikrostruktur untuk sampel 2 diperlihatkan pada gambar 7 bagian (a) dan (b). Hasil pengujian menunjukkan bahwa struktur mikro yang terbentuk sama seperti pada sampel 1. Sedangkan pada sampel 3 terdapat sulfide yang relatif lebih kecil dan martensit yang terbentuk relatif lebih sedikit dibandingkan dengan sampel 1 dan 2. Hal tersebut tidak memberikan dampak pada kerusakan pegas. Pada gambar juga menunjukkan struktur yang terbentuk berupa martensit halus dan austenite sisa berwarna putih namun lebih sedikit dibandingkan dengan sampel 1 dan 2.

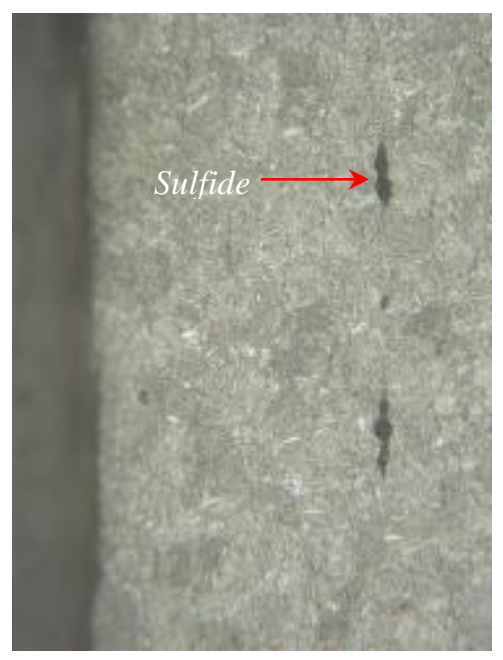

(a) Pembesaran 200x

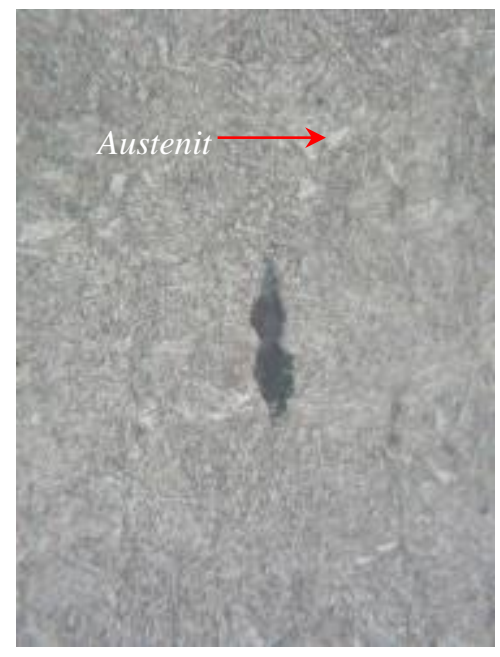

(b) Pembesaran 500x

Gambar 8. Hasil pengujian mikrostruktur pada sampel 3

\subsection{Kekerasan}

Pengujian kekerasan pegas daun bus yang mengalami kerusakan dilakukan pada 3 (tiga) lokasi, yaitu pada lokasi yang mengalami patah (sampel 1), lokasi sekitar patahan (sampel 2), dan pada lokasi material induk pegas (sampel 3).

Pengujian kekerasan pada masing-masing sampel dilakukan sebanyak 5 titik. Sampel uji kekerasan ditunjukkan pada Gambar 9 sedangkan data uji kekerasan ditunjukkan pada Tabel 1. 


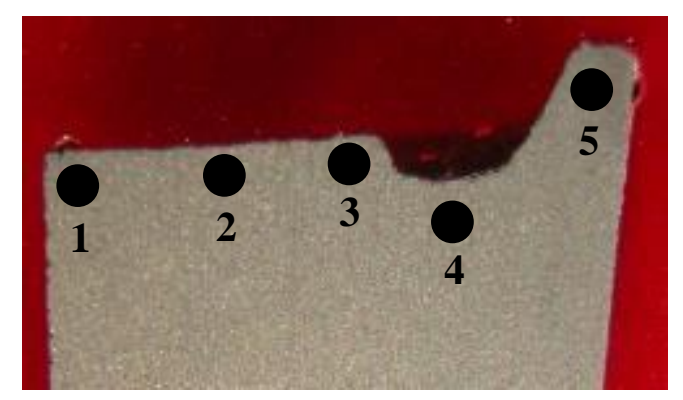

(a) Sampel 1

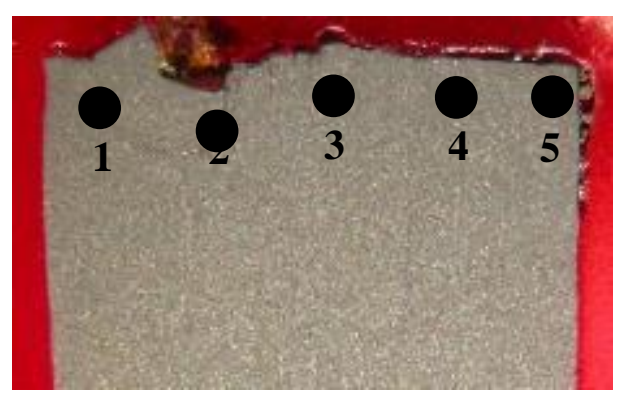

(b) Sampel 2

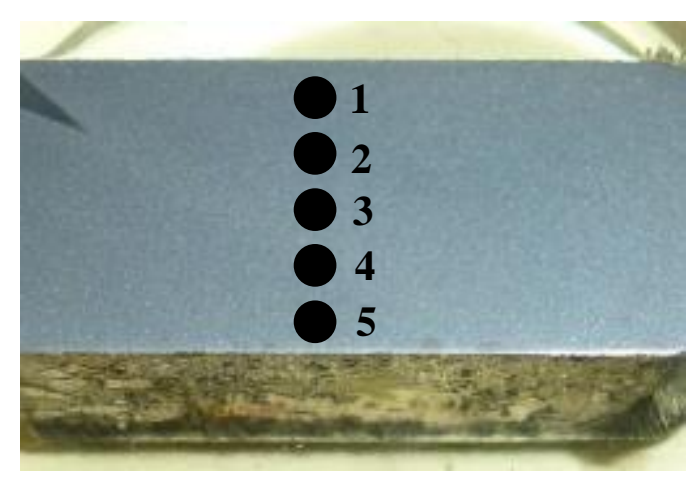

(c) Sampel 3

Gambar 9. Sampel uji kekerasann

Gambar 9 memperlihatkan titik sampel. Gambar (a) adalah sampel 1 yaitu pada lokasi patah pegas daun, gambar (b) adalah sampel 2 yaitu pada lokasi dekat dengan patahan pegas daun, dan gambar (c) adalah sampel 3 yaitu bagian terjauh dari titik patahan atau material induk pegas daun. Masing-masing sampel diambil 5 titik. Sementara itu tabel 1 menunjukkan bahwa nilai kekerasan rata-rata pada sampel 1 adalah sebesar $425 \mathrm{HV}$, sampel 2 sebesar 425 HV dan pada sampel 3 sebesar 428 HV. Gambar 10 pada grafik juga menunjukkan adanya fluktuasi hasuk pengujian kekerasan. Hasil pengujian kekerasan dan grafik dari ketiga sampel menunjukkan bahwa material masih berada dalam kisaran nilai standar dengan mengacu pada JASO C-601 dengan nilai 410-490 HV.

Tabel 1. Hasil uji kekerasan Sampel Pegas Daun

\begin{tabular}{|c|c|c|c|c|}
\hline \multirow{2}{*}{ NO. } & \multicolumn{3}{|c|}{ NILAI KEKERASAN, HV } & \multirow{2}{*}{ STANDAR JASO } \\
\cline { 2 - 4 } & \multicolumn{3}{|c|}{ PEGAS NO. 8 8 } \\
\cline { 2 - 4 } & SAMPEL 1 & SAMPEL 2 & SAMPEL 3 & \multirow{2}{*}{ 410-491 HV } \\
\hline 1 & 418 & 423 & 429 & \\
\hline 2 & 429 & 423 & 423 & \\
\hline 3 & 423 & 418 & 432 & \\
\hline 4 & 429 & 418 & 435 & \\
\hline 5 & 441 & 423 & $\mathbf{4 2 8}$ & \\
\hline Ratar-ata & $\mathbf{4 2 5}$ & $\mathbf{4 2 5}$ & & \\
\hline
\end{tabular}

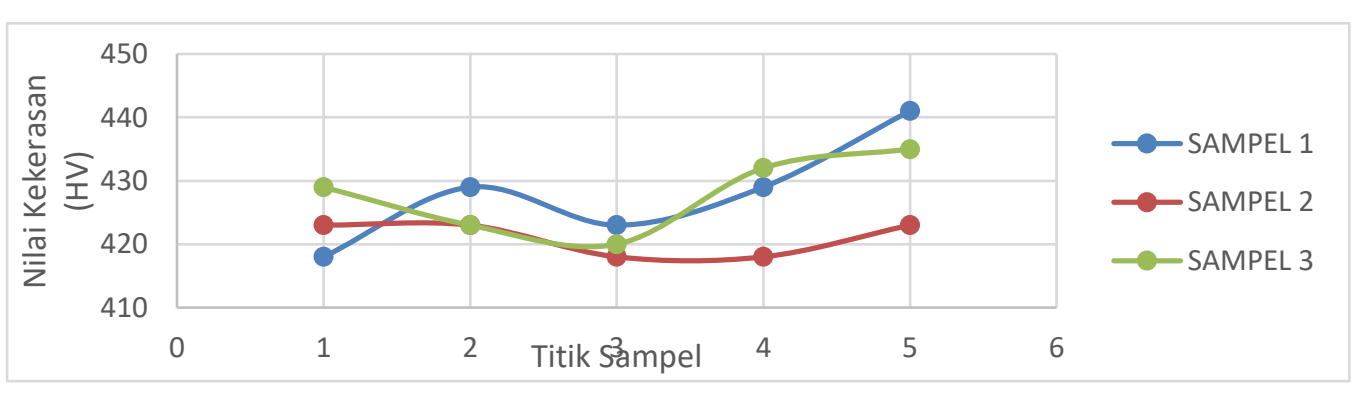

Gambar 10. Grafik Uji Kekerasan 


\subsection{Komposisi Kimia}

Pengujian komposisi kimia material sampel pegas daun dilakukan dengan menggunakan sparktrometer yaitu untuk mengetahui unsur kimia yang terkandung pada pegas daun. Data uji komposisi kimia material sampel pegas daun ditunjukkan pada tabel 2. Material sampel pegas bus terbuat dari baja karbon sedang atau setara dengan AISI 5160 ekuivalen JIS SUP 9A.

Tabel 2. Hasil pengujian komposisi kimia pegas daun

\begin{tabular}{|c|c|c|c|c|}
\hline \multirow{2}{*}{ No. } & Unsur & $\begin{array}{c}\text { Sampel Pegas Pada } \\
\text { Lokasi Patah }\end{array}$ & Sampel Pegas Induk & $\begin{array}{c}\text { Sampel Standar Pegas } \\
\text { Daun IIS SUP 9A }\end{array}$ \\
\cline { 3 - 5 } & $\begin{array}{c}\text { Nilai Kandungan unsur } \\
\text { (\% berat) }\end{array}$ & $\begin{array}{c}\text { Nilai Kandungan } \\
\text { unsur (\% berat) }\end{array}$ & $\begin{array}{c}\text { Nilai Kandungan unsur } \\
\text { (\% berat) }\end{array}$ \\
\hline 1 & $\mathrm{Fe}$ & 97.1 & 97.0 & \\
\hline 2 & $\mathrm{C}$ & 0.565 & 0.640 & $0.56-0.64$ \\
\hline 3 & $\mathrm{Si}$ & 0.260 & 0.260 & $0.15-0.35$ \\
\hline 4 & $\mathrm{Mn}$ & 0.759 & 0.759 & $0.70-1.00$ \\
\hline 5 & $\mathrm{Cr}$ & 0.675 & 0.782 & $0.70-1.00$ \\
\hline 6 & $\mathrm{~S}$ & 0.0110 & 0.0110 & $0.035 \mathrm{max}$ \\
\hline 7 & $\mathrm{P}$ & 0.0109 & 0.0109 & $0.035 \mathrm{max}$ \\
\hline 8 & $\mathrm{Cu}$ & 0.0165 & 0.0165 & $0.300 \mathrm{max}$ \\
\hline 9 & $\mathrm{Ni}$ & 0.0571 & 0.0456 & \\
\hline 10 & $\mathrm{Mo}$ & 0.0137 & 0.0137 & \\
\hline 11 & $\mathrm{Al}$ & 0.0138 & 0.0138 & \\
\hline 12 & $\mathrm{~V}$ & 0.0085 & 0.0085 & \\
\hline 13 & $\mathrm{~W}$ & $<0.0250$ & $<0.0250$ & \\
\hline 14 & $\mathrm{Ti}$ & 0.0033 & 0.0033 & \\
\hline 15 & $\mathrm{Nb}$ & 0.0061 & 0.0061 & \\
\hline 16 & $\mathrm{~Pb}$ & $<0.0150$ & $<0.0150$ & \\
\hline
\end{tabular}

Dari data Tabel 2 terlihat adanya penurunan unsur Cr sebesar 0,11\%, yaitu dari 0,782 menjadi 0,675. Penurunan kandungan $\mathrm{Cr}$ disebabkan oleh interaksi antara logam dengan ion oksigen air yang bertahan pada sela-sela pegas daun dalam rentang waktu yang relatif lama sehingga mengakibatkan terbentuknya oksida. Proses oksida pada logam pegas daun menyebabkan terjadinya korosi pada logam tersebut yang kemudian mempengaruhi penurunan unsur $\mathrm{C}$ sebesar $0,075 \%$ yaitu 0,640 menjadi 0,565 .

\section{Kesimpulan}

Berdasarkan hasil pengkajian data mikrostruktur, kekerasan dan komposisi kimia pegas daun pada bus, dapat disimpulkan sebagai berikut :

1. Struktur mikro pada sampel 1 dan sampel 2 menunjukkan adanya retakan yang disebut Sulphide Stress Cracking (SSC), hal tersebut menyebabkan terjadinya penurunan terhadap sifat keuletan dan deformasi pada material pegas daun. Selain itu terbentuk martensit halus dan austenite sisa berwarna putih, sehingga dapat disimpulkan faktor penyebab patahnya pegas daun adalah kurang pemeliharaan dan kelelahan material akibat beban dinamis.

2. Kekerasan material pegas daun pada lokasi patahan maupun pada sekitar patahan relatif sama dengan kekerasan pada lokasi material induk pegas daun, yaitu dengan nilai rata-rata sebesar $425 \mathrm{HV}$ terdapat pada sampel 1, $425 \mathrm{HV}$ pada sampel 2 dan sebesar $428 \mathrm{HV}$ terdapat pada sampel ke 3. Berdasarkan standar JASO C-601, bahwa nilai rata-rata kekerasan hasil uji tersebut tidak mempengaruhi kerusakan atau patahnya pegas daun.

3. Komposisi kimia jenis $\mathrm{Cr}$ yang terkandung pada pegas daun mengalami penurunan yaitu sebesar $0,11 \%$ dari 0,782 menjadi 0,675, dan penurunan unsur kimia $C$ sebesar $0,075 \%$ yaitu 0,640 menjadi 0,565.

\section{Daftar Pustaka}


1. Sularso, Kiyokatsu Suga. 1980. Dasar Perancangan dan Pemilihan Elemen Mesin. Jakarta : Pradya Pramita

2. Wijono, Djoko. 1994. Teori Praktikum Ilmu Logam. Jakarta : LUK-BPP Teknologi,.

3. Hari, Amanto dan Daryanto. 1999. Ilmu Bahan. Jakarta : Smar Grafika Offset

4. Vlack, Lawrence H. Van. 1989. Ilmu dan Teknologi Bahan. Jakarta : Erlangga

5. Callister, Jr., dan William D. (2007). Materials Science and Engineering. New York : John Wiley and Sons.

6. Smith, William F. 1996. Principle of Materials Science and Engineering (3rd Edition, International Edition). USA : Mc-Graw-Hill Inc.

7. Adisasmita, Rahardjo dan Adisasmita, Sakti Adji. 2011. Manajemen Transportasi Darat.. Jakarta : Graha Ilmu.

8. Xue, Z. Y. Ka dan Zhigao, H. 2011. "Finite element analysis of composite leaf spring, ” China : ICCSE

9. Sofyan, Bondan T. 2010. "Pengantar Material Teknik”. Jakarta : Salemba Teknika

10. Mamanal, Irwanto Putra. 2014. Pengaruh Temperatur Hardening Terhadap Peningkatan Sifat Mekanis Dan Struktur Mikro Leafspring Hijet 1ooo. Jakarta : Sekolah Tinggi Teknik Harapan

11. Daryono. 2007. "Analisa Umur Pegas Daun Pada Suspensi Kendaraan Roda Empat"

12. Hidayat,T. 2000. "Analisa Kegagalan Pegas Daun (Leaf Spring) Pada Toyota Kijang Kapsul 7K-EF"

13. Miftahurrozi, D., 2003. Optimasi Kelengkungan Lempengan Pegas Daun. UMM

14. Nanang, T.S., 2004. Distribusi tegangan pegas Daun pada Dump Truck. UMM.

15. Shankar, V., 2006. Mono Composite Leaf Spring for Light Weight Vehicle. Journal material Science 